\title{
Processing of Al-Fe Scraps by Powder Metallurgy
}

Vojtěch Kučera, Filip Průša, Dalibor Vojtěch

Department of Metals and Corrosion Engineering, University of chemistry and technology Prague, Technická 5, 16628 Prague 6, Czech Republic. E-mail: kucerao@vscht.cz

Iron has a low solubility in aluminium solid solution even at elevated temperatures and forms brittle intermetallic phases with needle-like or platelets-like morphology when it is produced by conventional casting technologies. These phases have a detrimental effect on mechanical properties. Therefore with increasing significance of recycling and also amount of aluminium scrap that needs to be recycled, it is necessary to find a promising ways of processing such waste materials. Powder metalurgy leads to intensive microstructural refinement, increases solid solubility of alloying elements and overall to improvement of mechanical properties. Hence, it belongs to promising alternatives for proccesing aluminium materials with increased amount of iron. Aluminium alloy with $17 \mathrm{wt}$ \% iron was prepared by centrifugal atomization and consolidated by spark plasma sintering followed by hot extrusion. The microstructure and phase composition of compact samples as well as mechanical properties were studied. Fine microstructure has been achieved by centrifugal atomization and consolidation by spark plasma sintering in combination with hot extrusion. Compression strength was $565 \mathrm{MPa}$ with remarkable ductility reaching almost $35 \%$.

Keywords: AlFe alloy, centrifugal atomization, spark plasma sintering, hot extrusion

\section{Acknowledgement}

The authors wish to thank the Czech Science Foundation (project no. P108/12/G043) for its financial support of this research.

The authors wish to thank the Financial support from specific university research (MSMT No 20-SVV/2016) for its financial support of this research.

\section{References}

[1] PRUSA, F., D. VOJTECH, DAM, K. (2012). Characterization of the Al-13Si-10Fe alloy produced by centrifugal atomization and ultra-high-pressure compaction. Kovove Materialy, 2012. 50(6): p. 399-406.

[2] DAM, K., PRUSA, F., VOJTECH, D. (2014). Structural and mechanical characteristics of the Al-23Si-8Fe-5Mn alloy prepared by combination of centrifugal spraying and hot die forging. Materials Science and Engineering: A, 2014. 610: p. 197-202.

[3] SASAKI, T. T., T. OHKUBO, HONO, K. (2009). Microstructure and mechanical properties of bulk nanocrystalline Al-Fe alloy processed by mechanical alloying and spark plasma sintering. Acta Materialia, 2009. 57(12): p. 3529-3538.

[4] VOJTECH, D., PRUSA, F., MICHALCOVA, A. (2010). Structural and mechanical characterization of rapidly solidified A195Ni5 and A193Ni5Mm2 alloys prepared by centrifugal atomization. Journal of Alloys and Compounds, 2010. 506(2): p. 581-588.

[5] SKOLAKOVA, A., et al. (2014). Production of Al-Si-Fe-X alloys by powder metallurgy. Manufacturing Techno$\log y, 2014.14(3)$ : p. 437-441.

[6] SASAKI, T. T., MUKAI, T. HONO, K. (2007). A high-strength bulk nanocrystalline Al-Fe alloy processed by mechanical alloying and spark plasma sintering. Scripta Materialia, 2007. 57(3): p. 189-192.

[7] SCHMITZ, C., DOMAGALA, J., HAAG, P. (2006). Handbook of Aluminium Recycling. 1 ed, ed. C. Schmitz. 2006: Vulkan-Verlag GmbH. 510.

[8] DOLEZAL, J., BRYKSI STUNOVA, B., KUCERA, V. (2015). Současné poznatky o vlivu doprovodných prvků ve slitinách Al-Si. Slévarenství, 2015. 63 (9-10): p. 345-348.

[9] KŘÍŽ, J. and P. NOVÁK, Thermally stable Al-Fe based alloys produced from secondary materials. Manufacturing Technology, 2015. 15(2): p. 155-161. 
[10] MICHNA, S., MAJRICH, P. (2012). Possible ways of obtaining an aluminium alloy by non-traditional waste processing of aluminium beverage containers. Manufacturing Technology, 2012. 12(13).

[11] Sběrné suroviny D. F. [cited 2016 5.3.]; Available from: http://www.centrum-odpadu.cz/ceniky/.

[12] BELOV, N. A., AKSENOV, A. A., ESKIN, D. G. (2002). Iron in Aluminium Alloys: Impurity and Alloying Element. Vol. 2. 2002, London: Taylor and Francis. 360.

[13] TAYLOR, J. A. (2012). Iron-Containing Intermetallic Phases in Al-Si Based Casting Alloys. Procedia Materials Science, 2012. 1: p. 19-33.

[14] SERAK, J., et al. (2008). Snížení obsahu železa ve slitinách AlSiCuMgFe, in METAL 2008. p. 6.

[15] PRUSA, F., VOJTECH, D. (2013). Mechanical properties and thermal stability of Al-23Si-8Fe-1Cr and Al-23Si8Fe-5Mn alloys prepared by powder metallurgy. Materials Science and Engineering: A, 2013. 565: p. 13-20.

[16] OZAKI, H., KUTSUNA, M. (2012). Dissimilar Metal Joining of Zinc Coated Steel and Aluminum Alloy by Laser Roll Welding. Welding Processes 2012; Available from: http:/www.intechopen.com/books/howtoreference/welding-processes/dissimilar-metal-joining-of-zinc-coated-steel-and-aluminum-alloy-by-laser-roll-welding.

[17] HO, K. H., ZHAO, Y. Y. (2004). Modelling thermal development of liquid metal flow on rotating disc in centrifugal atomisation. Materials Science and Engineering: A, 2004. 365(1-2): p. 336-340.

[18] ZHAO, Y. Y., JACOBS, M. H. DOWSON, A. L. (1998). Liquid flow on a rotating disk prior to centrifugal atomization and spray deposition. Metallurgical and Materials Transactions B, 1998. 29(6): p. 1357-1369.

[19] NEIKOV, O. D., (2009). Chapter 5 - Atomization and Granulation, in Handbook of Non-Ferrous Metal Powders, O.D.N.S.N.V.M.G.G.V.F.V. Lotsko, Editor. 2009, Elsevier: Oxford. p. 102-142.

[20] PRUSA, F., et al., (2014). Mechanical properties and thermal stability of Al-Fe-Ni alloys prepared by centrifugal atomisation and hot extrusion. Materials Science and Engineering: A, 2014. 603: p. 141-149.

[21] PRUSA, F., et al., (2015). Structure and mechanical properties of Al-Si-Fe alloys prepared by short-term mechanical alloying and spark plasma sintering. Materials \& Design, 2015. 75: p. 65-75. 